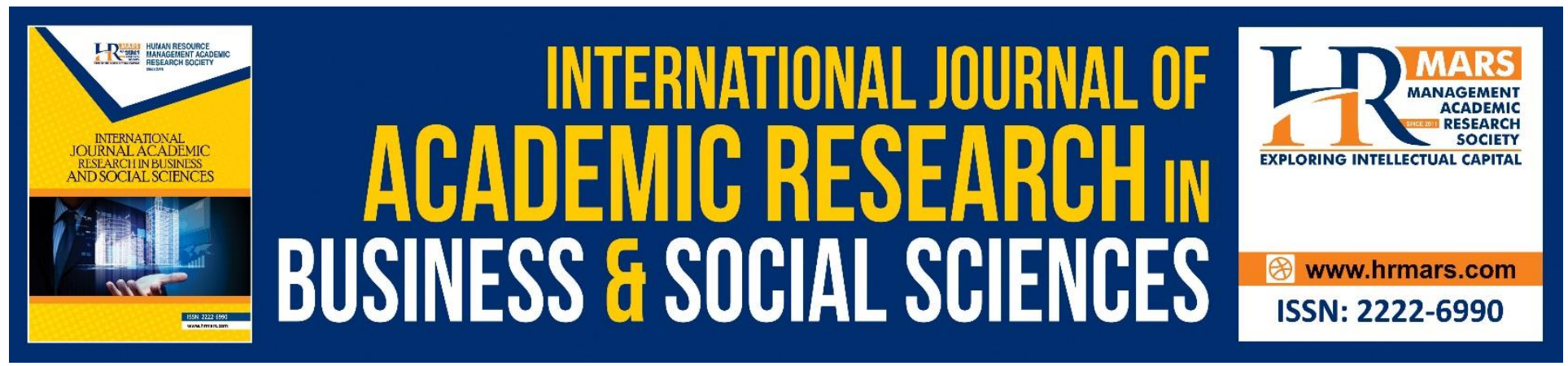

\title{
The Effect of Peer Influence on Sales Tax Compliance Among Jordanian SMEs
}

\section{Ahmad Farhan Alshira'h}

To Link this Article: http://dx.doi.org/10.6007/IJARBSS/v9-i3/5737

DOI: $\quad 10.6007 /$ IJARBSS/v9-i3/5737

Received: 06 Feb 2019, Revised: 26 Feb 2019, Accepted: 16 March 2019

Published Online: 23 March 2019

In-Text Citation: (Alshira'h, 2019)

To Cite this Article: Alshira'h, A. F. (2019). The Effect of Peer Influence on Sales Tax Compliance Among Jordanian SMEs. International Journal of Academic Research in Business and Social Sciences, 9(3), 710-721.

\section{Copyright: (C) 2019 The Author(s)}

Published by Human Resource Management Academic Research Society (www.hrmars.com)

This article is published under the Creative Commons Attribution (CC BY 4.0) license. Anyone may reproduce, distribute, translate and create derivative works of this article (for both commercial and non-commercial purposes), subject to full attribution to the original publication and authors. The full terms of this license may be seen at: http://creativecommons.org/licences/by/4.0/legalcode

Vol. 9, No. 3, 2019, Pg. 710 - 721

Full Terms \& Conditions of access and use can be found at http://hrmars.com/index.php/pages/detail/publication-ethics 


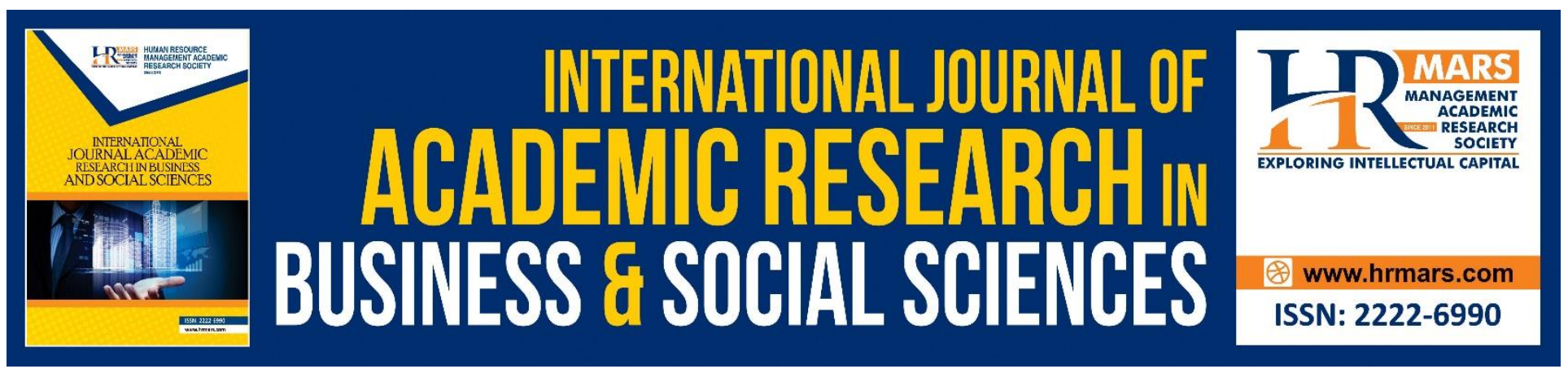

\title{
The Effect of Peer Influence on Sales Tax Compliance Among Jordanian SMEs
}

\author{
Ahmad Farhan Alshira'h \\ Faculty of Finance and Business Administration, Al al-Bayt University, Jordan \\ E-mail: Alshraah.ahmad@yahoo.com
}

\begin{abstract}
The purpose of this study is to examine the impact of peer influence on sales tax compliance of Jordanian small and medium enterprises (SMEs). While the impact of peer influence on income tax compliance has been examined by prior research, the effect of peer influence on sales tax compliance of SMEs has been neglected. Therefore, this study is the first to examine this relationship among Jordanian SMEs. A questionnaire has been used to collect data from the study sample, which consisted of 212 owner-managers of SMEs. The research hypothesis was then tested using PLS-SEM software. This study provides the first evidence that peer influence has an insignificant impact on sales tax compliance among Jordanian SMEs. According to the finding, the implications of the study as well as suggestions for future studies are also discussed.
\end{abstract}

Keywords: Sales tax compliance, Peer influence, SMEs, Jordan

\section{Introduction}

Governments need to earn revenue to cover their expenditures (Raza and Naqvi, 2016; Safakli and Kutlay, 2014). Taxes, one of the components providing social welfare, are collected for utilize in the financing of public expenditure such as health services, public infrastructure and education (Güzel et al., 2019). In Jordan, the primary source of government revenue is taxes, which contrasts with its neighbouring countries that are blessed with natural resources (i.e. oil) as the main form of government revenue (Alshira'h et al., 2018). Tax non-compliance shape is a major issue in the Jordanian economy, and has reached a high rate in tax revenue (AL-Shawawreh and AL-Smirat). The rise in the non-compliance of tax payment has a negative influence on the budget deficit in Jordan (Al-Naimat, 2013). This problem has led to an increase in public debt, which has led to a lack of tax justice among the citizens, and an increase in the rate of tax non-compliance, especially in respect of the sales tax. With regards to the amount of tax non-compliance, the professional and small enterprises represent $80 \%$ of non-compliance (Rawabdeh, 2015). This is because taxpayers in Jordan avoid paying tax using several different methods, and indicative of the high percentage of taxpayers who are late in paying taxes owed to the tax authority (Masadeh, 2015). The Jordanian Audit Bureau 
(2014) has indicated that large amount of tax due to the treasury from individuals and enterprises are yet to be received. The government must address the issue of tax non-compliance, as it has a considerable effect on the government revenue. Toukan (2014) declared that the size of tax noncompliance in Jordan is estimated to be around JD 1.5 billion. Qawasmi (2014) has also reported that tax non-compliance and corruption has increased in the financial statements in Jordanian companies. Over the years, in spite of the increase in tax revenue, the tax non-compliance has also increased from JD 1067.4 million in 2011 to JD 1578.2 million in 2015; sales tax non-compliance represented about $71 \%$ of the total tax non-compliance during the period mentioned above (Jordan Independent Economic Watch[JIEW], 2014; Jordan Economic Social Centre [JESC], 2014). As a result, the government of Jordan has resorted to borrowing from domestic or foreign sources to cover the expenditure (Alkhdour, 2011). Figure 1 shows the tax revenue of the Jordanian government and tax non-compliance from 2010 to 2015.

Figure 1 Tax Non-compliance and Tax Revenue in Jordan from 2010 -2015

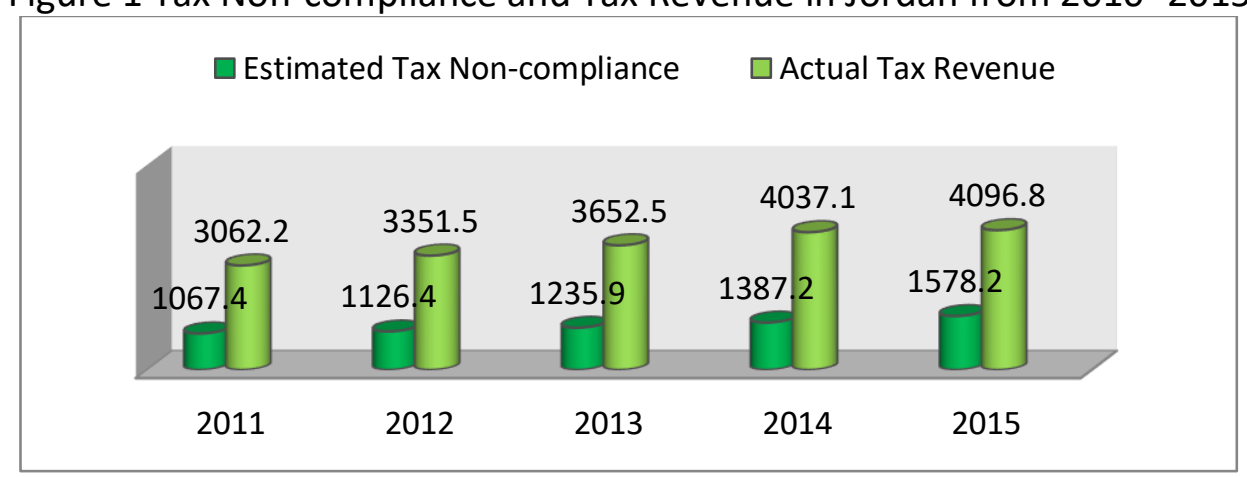

Source: Ministry of Finance (2015), Jordan and JESC (2014)

Figure 1.1 provides information about the size of tax revenue and tax non-compliance, for the sixyear period between 2010 and 2015. It can be seen that over this period, the increase in tax revenue rose from JD 2,986 million in 2010, to JD 4,370 million in 2015. Over this period there was also evidence that there was an increase in the tax non-compliance, which rose from JD 1067.4 million in 2011 to JD 1578.2 million in 2015. With regards to the SMEs, Pope and Abdul-Jabbar (2008) indicated that the SMEs around the globe are characterized by tax non-compliance. Alm and McClellan (2012) found that small businesses may find it very easy to avoid the attention of the tax department, and, thus, lower tax compliance. YEA (2011) found that around $87 \%$ of small enterprises and $35 \%$ of medium enterprises did not pay their sales tax in Jordan, which is all the more worrying as SMEs represent more than $99 \%$ of the total enterprises in Jordan. The factors contributing to the tax compliance behavior of SMEs is yet to be fully ascertained. Therefore, this study aims to investigate the effect of peer influence on sales tax compliance in Jordanian SMEs.

The rest of the paper is organized as follows. The next section reviews the past literature and hypothesis development. The methodology and data analyses in addition to the conclusions, recommendations and suggestions for the future studies are finally reported.

\section{Literature Review}

In the current study, two variables were used as the peer influence and sales tax compliance. Literature research of these variables were made and hypotheses of the study were established. 


\section{Sales Tax Compliance}

There is a shortage of obvious definitions of tax non-compliance and tax compliance (Randlane, 2016). Research on tax compliance start in the early 1970s, during the time that the decision to comply with tax law was framed as a completely economic decision (Alm et al., 2012). Thus, tax compliance considers as a comparatively new research scope (Alm and Torgler, 2011). Taxes are financial assets of a state and have a vital role within the country's improvement (Nurkhin et al., 2018). Compliance with taxpayers is still an interesting subject to study and it is seen as a main issue for most tax authorities in the world. Tax compliance basically means the declaration of all taxpayers ' income and the payment of all taxes in accordance with their legal obligations (Alm, 1991). In accordance with legal regulations, it describes tax compliance as the preparation and reporting of tax returns by taxpayers on time and accurately. In the simplest way, James and Alley (2002) defines compliance with taxation is the level of compliance with tax law by taxpayers This problem has affected most developing countries in comparison with developed countries (Kim, 2008). In Brown and Mazur (2003), the authors revealed the multiple faceted measures of tax compliance, where the taxpayers' compliance are of three types namely, reporting compliance, filing compliance and payment compliance.

More specifically, in the sales tax context, compliance is referred to as the adherence with the entire procedures and legislation, with the inclusion of actual and correct sales paid and collected reporting, actual sales liability, payment of the entire due taxes timely, and timely filing of tax returns (Nura et al., 2017). Sales tax compliance is the ability of a body or business entity to submit the accurate, complete as well as sales tax satisfactory returns in conformity with all the regulations and sales tax law of a tax authority (Ocheni, 2015). In contrast, tax non-compliance was highlighted as a main phenomenon that destroyed the collection of revenue needed to improve public facilities. However, research non-compliance or compliance with indirect taxes is still negligible. In the context of sales tax. Accordingly, non - compliance with the sales tax is a common phenomenon involving the manipulation of the sales tax invoice and the alteration of tax reports in order to achieve personal benefits, such as paying less sales tax, increasing earnings and reducing costs. Therefore, compliance with the sales tax is defined as a correct record of the sales tax invoice details, instead of being fraudulent in the tax invoice details to pay less sales tax.

\section{Peer Influence}

Past literature has ascertained the importance of peer influence. Clotfelter (1983) claimed that peer play a significant role in tax compliance, although the study does not discuss which is stronger: friends or family members. The term peers are defined generally as a taxpayer's associates that can be relatives, friends, co-workers and colleagues (Jackson and Milliron, 1986). Peer groups have a potent effect on preferences, behaviour and personal values of taxpayers (Puspitasari and Meiranto, 2014). Hence, Lefebvre et al. (2015) reported the significance of not ignoring the presence of peer impact when examining the tax compliance behaviour. Chau and Leung (2009) stated that peers' influences are reflected in taxpayer's anticipations in relation to the disapproval or approval of tax noncompliance, whereas Alm and McKee (1998) declared that the social norms are a major determinant of tax compliance. The present study defines peer influence as the effect of people who are significant 
for SMEs' owner-managers on their sales tax compliance decision, thus contributing in shaping their attitude towards sales tax compliance.

From a socio-psychological perspective, a taxpayers' behaviour is defined by social norms to a considerable extent (Edlund and Aberg, 2002) which assist in determining tax obligation intentions (Bobek et al., 2007). These social norms are four types. First, the personal norms are one's own selfbased anticipations and standards of suitable behaviour. Second, the descriptive norms are criteria that develop through monitoring how others indeed behave in special statuses. Third, the injunctive norms are standards that determine what must be done, characterizing what the group disapproves or approves (e.g. community may sanction tax non-compliance as highly unethical). Finally, the subjective norms are related particularly to the anticipations of significant others (e.g. Friends, family, coworkers) (Onu and Oats, 2014; Bobek et al., 2013; Bobek et al., 2007). Added to the above studies, Maxwell (2002) pointed out that peer norms help define whether a behaviour is undesirable or desirable. In SMEs, peers have influences on tax obligation behaviour of their counterparts, and SMEs will evade tax payment if they felt that their peers were evading with punishment (Maseko, 2014; Omweri et al., 2010). Hence, a taxpayer is affected by the perception of the behaviour of other peer's taxpayers. In contrast, if the taxpayers think others to be honest, tax moral rises (Frey and Torgler, 2007). However, the relation between tax compliance and social norms are complex (Kirchler et al., 2008).

Some previous studies on tax compliance behaviour found a positive relation between tax compliance and peer influence (e.g., William, 2015 ;Bobek et al., 2013; Çevik and Yeniçeri, 2013; Tusubira and Nkote, 2013; Benk et al., 2011; Omweri et al., 2010). On the other hand, some other studies on tax compliance behaviour found a negative relation between tax compliance and peer influence (e.g., O'Shaughnessy, 2014; Alon and Hageman, 2013; Torgler, 2012; Frey and Torgler, 2007). However, some other studies declared that the peer influence has no impact on the tax reporting decisions (Wenzel, 2004; Chan et al., 2000). Given this research, the next hypothesis is presented as follows:

$\mathrm{H} 1$ : There is a positive relationship between peer influence and sales tax compliance.

\section{Study Model}

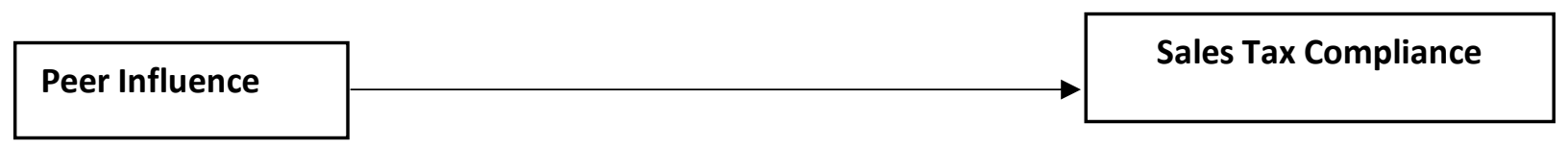

Figure 1. Research Framework

\section{Methodology \\ Data Collection}

The analysis unit of this research is at the organization level. Data were collected from 660 SMEs obtained from Jordan Chamber of Industry (JCI) data base for the year 2017. The questionnaires distributed based on probability sampling technique. Targeted respondents are owner-managers of this SMEs. Based on Sekaran and Bougie (2016) a response rate of $30 \%$ and above is acceptable for a 
INTERNATIONAL JOURNAL OF ACADEMIC RESEARCH IN BUSINESS AND SOCIAL SCIENCES

Vol. 9, No. 3, March, 2019, E-ISSN: 222 2-6990 ¿ 2019 HRMARS

survey. Additionally, Baruch and Holtom (2008) have also suggested that around $30 \%$ of the response rate from the organizational level is acceptable.

\section{Measurement}

All the items of variable in this quantitative research design employed adapted from prior studies. All the items have been measured based on five-point Likert-scale ranging from strongly disagree (1) to strongly agree (5). The 11 items for sales tax compliance adapted from Woodward and Tan (2015). Using tax invoice means that business becomes liable for sales tax once the invoice. For measuring peer influence, 6 items were adapted from Braithwaite (2001).

\section{Data Analysis}

This study develops a structural model to test a hypothesis in which the model draws a direct path between peer influence and sales tax compliance. Partial Least Squares (PLS) analysis technique utilizing Smart PLS software employed to analyze research model. Following the rule of thumb suggested by Hair, Ringle and Sarstedt (2011). The two-step procedure employed in this study include measurement model (inner model) as well as the structural model (outer model).

\section{Assessment of Measurement Model}

Table 1 Result of Measurement Model

\begin{tabular}{lcccc}
\hline Latent construct & Items & Loading & CR & AVE \\
\hline Sales Tax Compliance (STC) & STC1 & 0.818 & 0.883 & 0.519 \\
& STC2 & 0.819 & & \\
& STC3 & 0.726 & & \\
& STC4 & 0.695 & & \\
& STC5 & 0.665 & & \\
& STC8 & 0.643 & & \\
\hline Peer Influence (PI) & STC9 & 0.659 & & 0.517 \\
& PI3 & 0.923 & 0.771 & \\
\hline
\end{tabular}

As shown in Table 1. STC6, STC7, STC10, STC11, PI1, PI2, PI5 were deleted because of low loadings of less than 0.50 as suggested by Hair et al. (2014) to increase the values of CR and the AVE of the related latent variables to the minimum acceptable value, thus necessitating the removal of a number of items from these constructs to establish reasonable reliability. The measurement model estimated through convergent validity and discriminant validity. The convergent validity assessed by estimating the indicators loadings, composite reliability and average variance extracted (AVE). As demonstrated in Table 1. Using Hair et al. (2016) as bases, construct validity was ascertained if the indicator loadings were above 0.4 , composite reliability was greater than 0.7 , the average variance extracted was greater than 0.5 .

After the convergent validity assessed, next is examine the discriminant validity following Fornell and Lacker's (1981) recommendation. The comparison was made with AVE's square root values with 
the correlations of the latent variable. As illustrated in Table 2, the square root of AVE's is greater than all cases and the diagonal values in the respective rows and columns. Thus, this indicates the adequate discriminant validity achieved. Overall, the measurement model shown the satisfactory convergent validity and discriminant validity.

Table 2 Latent Variable Correlations and Square Roots of the Average Variance Extracted

\begin{tabular}{lll}
\hline & STC & TF \\
\hline STC & 0.721 & \\
\hline TF & 0.038 & 0.734 \\
\hline
\end{tabular}

As reported in Table 2, the correlation values for each of the study variables is less than the square root of the average variance extracted. Thus, an adequate discriminant validity of the variables is reached (Hair et al., 2010).

\section{Assessment of Structural Model}

The predictive power of research model evaluated by $\mathrm{R}^{2}$ (coefficient of determination) shows the joint effect of exogenous variables on endogenous variable (Wong, 2013). The SmartPLS software function applied to obtain the $R^{2}$ value to assess the amount of variance explained by exogenous variables (Hair et al., 2016). The variable showed $R^{2}$ value of .122 indicating $12.2 \%$ of the variance in the sales tax compliance explained by peer influence. The bootstrapping function with 5000 resampling from 212 cases performed. Moreover, the path estimates and t-values calculated for the hypothesized association. Table 2 , illustrates the findings of structural model's analysis. The findings declared that peer influence $(\beta=0.060, p<0.217)$ insignificant related to sales tax compliance which not supported $\mathrm{H} 1$.

Table 2 Structural Model PLS-SEM

\begin{tabular}{clcccl}
\hline Hypothesis No. & $\begin{array}{l}\text { Relationshi } \\
\mathbf{p}\end{array}$ & $\begin{array}{l}\text { Path } \\
\text { coefficient }\end{array}$ & T-Value & $\mathbf{P}$-Value & Decision \\
\hline $\mathrm{H} 1$ & $\mathrm{PI}->\mathrm{STC}$ & 0.060 & 1.235 & $0.217^{*}$ & Not Supported \\
\hline $\mathrm{R}^{2}$ sales tax compliance $=0.122 ; \mathbf{Q}^{2}$ sales tax compliance $=0.006$ & \\
\hline
\end{tabular}

\section{Conclusions and Recommendations}

The present study was designed to test the significance of peer influence on owner-managers' decisions to pay their sales tax. Tax moral is one of the major factors influencing tax compliance (Jackson and Million, 1986). The term peers are defined generally as the associates of a taxpayer who rationally comprise relatives, friends, co-workers and colleagues (Jackson and Milliron, 1986). Chau and Leung (2009) stated that peer influences are reflected in taxpayer's anticipations in relationship to the disapproval or approval of tax non-compliance, while Alm and McKee (1998) declared that peer influence is a major determinant of tax compliance. Peers could influence managers who are making tax decisions for business (Hasan et al., 2017). Consequently, the current study hypothesized that a significant positive association would exist between peer influence and sales tax compliance $(\mathrm{H} 1)$.

Contrary to the expectations of this study, peer influence did not have any significant effect on sales tax compliance among Jordanian SMEs, and, thus, the proposed hypothesis was not supported. 
Therefore, the current result is not in alignment with the socio-psychological approach (Bandura, 1969). The social learning explains that compliance occurs when a taxpayer accepts influence from another taxpayer (Kelman, 1961). The result also does not align with most previous studies, which stated that an association existed between peer influence and sales tax compliance of SMEs (Woodward and Tan, 2015; Adams and Webley, 2001). Previous studies with similar results for this specific relationship are rare. In general, this result is also not in accordance with previous studies relating peer influence and income tax compliance as a tax behaviour (Chan et al., 2000; Hite, 1988). Peer influence may be unable to increase the tax compliance behaviour of the general population (Chung and Trivedi, 2003). The influence of peers had an insignificant impact on the compliance behaviour of the taxpayers (Bornman, 2014).

Peer influence would have no influence on the level of tax compliance of those who did not identify with the group (Wenzel, 2004). However, taxpayers are compliant even if they believe others are not compliant (Braithwaite et al., 2001). Peer influence is complex because it includes compliance associated with social pressure (Venkatesh and Davis, 2000). One possible explanation for the insignificant result in this current study is that the effect of peer influence on sales tax compliance decision may be attributed to the fact that tax compliance is purely a personal decision (Sukono and Djamaluddin, 2018). Another possible explanation for this is that the tax behaviour of a peer may be a private act and true peer behaviour is unobservable and, therefore, difficult to mimic (Hite, 1989). This rationale in the line with Bobek et al. (2007) who indicated that tax compliance behaviour is not easily observable. A third plausible explanation for the result could be explained by the characteristics of the Jordanian culture. Jordanians place great importance on individualism, self-confidence and self-autonomy; thus, they may not be impacted by their peers (Lutfi et al., 2017). To conclude, Jordanian SMEs in this survey considered peer influence as not having a direct effect on their decision for sales tax compliance, and, so, peer influence did not play an important role in promoting sales tax compliance among Jordanian SMEs.

The study contributes to current literature by providing a first evidence that peer influence has an insignificant impact on the sales tax compliance of Jordanian SMEs. Moreover, there is a very small body of literature that addresses sales tax compliance issues from a socio-psychological aspect, to date, there has been no work that test the effect of peer influence on sales tax compliance among SMEs in Arab countries and middle east especially in the context of Jordan. Issues of sales tax compliance of SME are of interest to policymakers. Information gathered from this study could assist the government when considering the goal, design and implementation of tax reforms for effective administration of future tax policies, particularly in developing countries.

Future research can build on the important factor in this research by introducing new factors and measures for sales tax compliance. Future research should look into extending the model to include other untested factors from economic, socio-psychological factors such as tax complexity, the financial condition, tax fairness.

\section{References}

Adams, C., \& Webley, P. (2001). Small business owners' attitudes on VAT compliance in the UK. Journal of Economic Psychology, 22(2), 195-216.

Alasfour, F. (2017). Costs of distrust: The virtuous cycle of tax compliance in Jordan. Journal of 
Business Ethics, 1-16.

Alkhdour, R. (2011). Estimating the shadow economy in Jordan: causes, consequences, and policy implications. (Unpublished doctoral thesis, Colorado State University).

Alm, J. (1991). A perspective on the experimental analysis of taxpayer reporting. The Accounting Review, 66(3), 577-593.

Alm, J., \& McKee, M. (1998). Extending the lessons of laboratory experiments on tax compliance to managerial and decision economics. Managerial and Decision Economics, 19(4), 259-275.

Alm, J., \& Torgler, B. (2011). Do ethics matter? Tax compliance and morality. Journal of Business Ethics, 101(4), 635-651.

Alm, J., Kirchler, E., Muehlbacher, S., Gangl, K., Hofmann, E., Kogler, C., \& Pollai, M. (2012). Rethinking the research paradigms for analysing tax compliance behaviour. In CESifo forum (Vol. 13, No. 2, pp. 33-40). München: ifo Institut-Leibniz-Institut für Wirtschaftsforschung an der Universität München.

Al-Naimat, S. M. A. (2013). Theoretical and analytical study of tax law in Jordan according to the: income tax and sales tax and its relationship with revenues and tax evasion. International Journal of Financial Research, 4(3), 107-126.

Alon, A., \& Hageman, A. M. (2013). The impact of corruption on firm tax compliance in transition economies: Whom do you trust? Journal of Business Ethics, 116(3), 479-494.

AL-Shawawreh, T. B., \& AL-Smirat, B. Y. (2016). Economic Effects of Tax Evasion on Jordanian Economy. International Journal of Economics and Finance, 8(7), 344-348.

Alshir'ah, A. F., Abdul-Jabbar, H., \& Samsudin, R. S. (2016). Determinants of sales tax compliance in small and medium enterprises in Jordan: A call for empirical research. World Journal of Management and Behavioral Studies, 4(1), 41-46.

Alshira'h, A. F., Abdul-Jabbar, H., \& Samsudin, R. S. (2018). Sales tax compliance model for the Jordanian small and medium enterprises research. Journal of Advanced Research in Social and Behavioural Sciences, 10(2), 115-130.

Bandura, A. (1969). Social-learning theory of identificatory processes. Handbook of socialization theory and research, 213, 262.

Baruch, Y., \& Holtom, B. C. (2008). Survey response rate levels and trends in organizational research. Human relations, 61(8), 1139-1160.

Benk, S., Çakmak, A. F., \& Budak, T. (2011). An investigation of tax compliance intention: a theory of planned behavior approach. European Journal of Economics, Finance and Administrative Sciences, 28, 180-188.

Bobek, D. D., Hageman, A. M., \& Kelliher, C. F. (2013). Analyzing the role of social norms in tax compliance behavior. Journal of Business Ethics, 115(3), 451-468.

Bobek, D. D., Roberts, R. W., \& Sweeney, J. T. (2007). The social norms of tax compliance: Evidence from Australia, Singapore, and the United States. Journal of Business Ethics, 74(1), 49-64.

Bornman, M. (2014). Principles for understanding, encouraging, and rewarding voluntary tax compliance (Doctoral dissertation, University of Johannesburg).

Braithwaite, V. (2001). The community hopes, fears and actions survey: Goals and measures (Working Paper No. 2). Centre for Tax System Integrity, the Australian National University. Braithwaite, V., Reinhart, M., Mearns, M., \& Graham, R. (2001). Preliminary findings from the 
community hopes, fears and actions survey: Goals and measures. (Working Paper No 3). Centre for Tax System Integrity, Canberra: The Australian National University.

Brown, R. E., \& Mazur, M. J. (2003). IRS's comprehensive approach to compliance measurement. National Tax Journal, 689-700.

Çevik, S., \& Yeniçeri, H. (2013). The relationship between social norms and tax compliance: The moderating role of the effectiveness of tax administration. International Journal of Economic Sciences, 2(3), 166-180.

Chan, C. W., Troutman, C. S., \& O’Bryan, D. (2000). An expanded model of taxpayer compliance: Empirical evidence from the United States and Hong Kong. Journal of International Accounting, Auditing and Taxation, 9(2), 83-103.

Chau, G., \& Leung, P. (2009). A critical review of Fischer tax compliance model: A research synthesis. Journal of Accounting and Taxation, 1(2), 34-40.

Chung, J., \& Trivedi, V. U. (2003). The effect of friendly persuasion and gender on tax compliance behavior. Journal of Business Ethics, 47(2), 133-145.

Clotfelter, C. T. ( 1983 ). Tax evasion and tax rates: An analysis of individual returns. The Review of Economics and Statistics, 65 (3), 363-373. doi: 10.2307/192418

Edlund, J., \& Aberg, R. (2002). Social norms and tax compliance. Swedish Economic Policy Review, 9(1), 201-231.

Fornell, C., \& Bookstein, F. L. (1982). Two structural equation models: LISREL and PLS applied to consumer exit - voice theory. Journal of Marketing Research,15, 440 - 452

Frey, B., \& Torgler, B. (2007). Taxation and conditional cooperation. Journal of Comparative Economics, 35, 136-159.

Güzel, S. A., Özer, G., \& Özcan, M. (2019). The effect of the variables of tax justice perception and trust in government on tax compliance: The case of Turkey. Journal of Behavioral and Experimental Economics, 78, 80-86.

Hair Jr, J. F., Hult, G. T. M., Ringle, C., \& Sarstedt, M. (2016). A primer on partial least squares structural equation modeling (PLS-SEM). Sage Publications.

Hair Jr, J., Sarstedt, M., Hopkins, L., \& G. Kuppelwieser, V. (2014). Partial least squares structural equation modeling (PLS-SEM) An emerging tool in business research. European Business Review, 26(2), 106-121.

Hair, J. F., Black, W. C., Babin, B. J., \& Anderson, R. E. (2010). Multivariate data analysis: Global edition.

Hair, J. F., Ringle, C. M., \& Sarstedt, M. (2011). PLS-SEM: Indeed a silver bullet. Journal of Marketing theory and Practice, 19(2), 139-152.

Hasan, I., Hoi, C. K., Wu, Q., \& Zhang, H. (2017). Social capital and debt contracting: Evidence from bank loans and public bonds. Journal of Financial and Quantitative Analysis, 52(3), 1017-1047.

Hite, P. A. (1988). The effect of peer reporting behavior on taxpayer compliance. Journal of the American Taxation Association, 9(2), 47-64.

Jackson, B. R., \& Milliron, V. C. (1986). Tax compliance research: Findings, problems, and prospects. Journal of accounting literature, 5(1), 125-165.

Jordan Economic and Social Council. (2014). Tax evasion in Jordan: causes, ways. www.esc. Jo Jordan Economic Social Centre. (2014). Tax evasion in Jordan: causes, ways. www.esc. jo Jordan Independent Economic Watch. (2014). Tax burden in Jordan, reality \& prospects. 
INTERNATIONAL JOURNAL OF ACADEMIC RESEARCH IN BUSINESS AND SOCIAL SCIENCES

Vol. 9, No. 3, March, 2019, E-ISSN: 222 2-6990 @ 2019 HRMARS

www.identity-center.org

Jordanian Audit Bureau (2014, October, 10). Jordan claims accounting persons and companies because of tax evasion. Raialyoum. Retrieved from http://www.raialyoum.com/?p=163700 Kelman, H. C. (1961). Three processes of social influence. Public Opinion Quarterly, 25, 57-78.

Kim, S. (2008). Does political intention affect tax evasion?. Journal of Policy Modeling, 30(3), 401-415. Kirchler, E., Hoelzl, E., \& Wahl, I. (2008). Enforced versus voluntary tax compliance: The "slippery slope" framework. Journal of Economic Psychology, 29(2), 210-225.

Lefebvre, M., Pestieau, P., Riedl, A., \& Claire, M. (2015). Tax evasion and social information : An experiment in Belgium , France, and the Netherlands. International Tax and Public Finance, 22(3), 401-425. https://doi.org/10.1007/s10797-014-9318-z

Lutfi, A. A., Idris, K. M., \& Mohamad, R. (2017). AIS usage factors and impact among Jordanian SMEs: The moderating effect of environmental uncertainty. Journal of Advanced Research in Business and Management Studies, 6(1), 24-38.

Maseko, N. (2014). The impact of personal tax knowledge and compliance costs on tax compliance behaviour of SMEs in Zimbabwe. Elite Research Journal of Accounting and Business Management, 2(3), 26-37.

Maxwell, K. a. (2002). Friends: The role of peer influence across adolescent risk behaviors. Journal of Youth and Adolescence, 31(4), 267-277. https://doi.org/10.1023/a:1015493316865

Ministry of Finance (2015). General government financial statements. General Government Bulletins for December. Retrieved from http://www.mof.gov. jo

Ministry of Finance (2016). General government financial statements. General Government Bulletins for December. Retrieved from http://www .mof.gov.jo /Portals/0/Mof_content/20\% 20\%//نشرة20\%مالية20\%الحكومة/2016 والبيانات20\%المالية 2016.pdf.

Moeinadin, M., Heirany, F., \& Harandi, A. (2014). Identifying the Effective Factors for the Improvement of Tax Compliance. International Journal of Academic Research in Accounting, Finance and Management Sciences, 4(1), 220-227.

Nsour, M. (2014). Tax evasion in Jordan: Causes, means and size. The Jordan Times Newspaper, 3 June, retrieved from: Jordantimes.com/tax- evasion-in-Jordan--causes-means-and-size. Accessed 24 March 2017. https://doi.org/10.16953/deusbed.74839

Nura, M., Abdul-Jabbar, H., \& Ibrahim, I. (2017). VAT Compliance and the Influence of Political and Business Environment: A Proposed Framework for Nigerian SMEs. Asian Journal of Business Management Studies, 8(2), 13-20.

Nurkhin, A., Novanty, I., Muhsin, M., \& Sumiadji, S. (2018). The influence of tax understanding, tax awareness and tax amnesty toward taxpayer compliance.Jurnal Keuangan dan Perbankan, 22(2).

O'Shaughnessy, D. (2014). Tax compliance determinants: A proposed model for cross-country analysis. (Unpublished doctoral thesis), University of Taxas at El Paso. Retrieved from http://digitalcommons.utep.edu/dissertations/AAI3636430/

Ocheni, S. (2015). A causality analysis between tax compliance behaviour and Nigerian economic growth. Mediterranean Journal of Social Sciences, 6(1 S1), 577.

Omweri, L., Miqwi, W., \& Obara, M. (2010). Taxpayers ' attitudes and tax compliance behaviour in kenya how the taxpayers ' attitudes influence compliance behaviour among smes business 
INTERNATIONAL JOURNAL OF ACADEMIC RESEARCH IN BUSINESS AND SOCIAL SCIENCES

Vol. 9, No. 3, March, 2019, E-ISSN: 222 2-6990 @ 2019 HRMARS

income earners in Kerugoya. African Journal of Business \& Management, 1(8), 112-122.

Onu, D., \& Oats, L. (2014). Social norms and tax compliance (Working Paper No. 006-14). Tax Administration Research Centre.

Puspitasari, E., \& Meiranto, W. (2014). Motivational postures in tax compliance decisions: an experimental studies. International Journal of Business, Economics and Law, 5(1), 100-110.

Qawasmi, H. (2014, March, 24). Chartered accountants warns of increased the tax evasion and financial corruption in Jordanian companies. All of Jordan Newspaper. Retrieved from http://www.allofjo.net/index.php?page $=$ article\&id $=66469$.

Rawabdeh, O. (2015, June,1). Tax evasion leads to the increase of public debt. Alrai Newspaper. Retrieved from http://www.alrai. com /article/717131.html.

Raza, S. H., \& Naqvi, S. M. A. (2016). Impact of Tax Evasion on Total Tax in Pakistan. International Journal of Academic Research in Business and Social Sciences, 6(11), 730-739.

Safakli, O. V., \& Kutlay, K. (2014). A Research on Students' Tax Compliance: Case OF European University of Lefke. International Journal of Academic Research in Economics and Management Sciences, 3(2), 1-7.

Sekaran, U., \& Bougie, R. (2016). Research methods for business: A skill building approach. John Wiley \& Sons.

Sukono, S., \& Djamaluddin, S. (2018). Analysis on the effects of social norms on local property tax compliance. Competition and Cooperation in Economics and Business.

Torgler, B. (2012). Tax morale, eastern Europe and European enlargement. Communist and PostCommunist Studies, 45(1-2), 11-25.

Torgler, B., \& Schneider, F. (2009). The impact of tax morale and institutional quality on the shadow economy. Journal of Economic Psychology, 30(2), 228-245.

Toukan, U. (2014, February, 11). Billion and a half JD the size of the tax evasion in Jordan. Assabel Newspaper. Retrieved from http://assabeel.net/local/item /25756

Tusubira, F. N., \& Nkote, I. N. (2013). Social norms, taxpayers" morale and tax compliance among SBEs in Uganda. Journal of Accounting, Taxation and Performance Evaluation, 2(1), 1-10.

Venkatesh, V., \& Davis, F. D. (2000). A theoretical extension of the technology acceptance model: Four longitudinal field studies. Management science, 46(2), 186-204.

Wenzel, M. (2005). Motivation or rationalisation? Causal relations between ethics, norms and tax compliance. Journal of Economic Psychology, 26(4), 491-508.

William, M. (2015). The influence of social norms and tax system on tax compliance. a case study of small and medium taxpayers in Tanga city- Tanzania (Unpublished doctoral thesis, University of Tanzania).

Wong, K. K. K. (2013). Partial least squares structural equation modeling (PLS-SEM) techniques using SmartPLS. Marketing Bulletin, 24(1), 1-32.

Woodward, L., \& Tan, L. M. (2015). Small business owners' attitudes toward GST compliance: a preliminary study. Australian Tax Forum, 30, 517.

Young Entrepreneure Association. (2011). Small and medium business agenda. Http://www.cipeArabia.org/. 